\title{
THE JEWS IN FINLAND AND WORLD WAR II
}

\author{
Tapani Harviainen \\ Helsinki \\ $-\infty-$
}

In several respects the history of the Jews in Finland has no counterpart, either in the Scandinavian and Baltic countries or in Eastern Europe. In order to be able to tell what happened during the Second World War, I must explain how there came to be Jews in Finland in that period. As a consequence, this presentation consists of two parts: first, the rise of the Jewish community in Finland, and, second, the fate of the Jews in Finland during the Second World War.

In theory, there was no place for Jews in Finland. From the I2th-I3th century until I809 Finland was a province of Sweden. When Sweden was opened up to the Jews in 1782 , residential rights were restricted to three, later four, cities on the Swedish mainland (Stockholm, Gothenburg, Norrköping; Karlskrona). Consequently, Jews were not allowed to settle in Finland. Nevertheless, visits were allowed and thus we know that the first Jews attested in Finland were the "Portuguese singers" Josef Lazarus, Meijer Isaac and Pimo Zelig, who together with the conjurer Michel Marcus were granted a licence to present their skills in Helsinki in I782. ${ }^{1}$

During the Swedish period some Jewish converts to Christianity also settled in Finland. Isak Zebulon of Lübeck, who had by baptismal received the name Christoffer, chose Oulu in Northern Finland as his new home town. The mother of Zacharias Topelius, the well-known Finnish writer (1818I898), was descended from this Oulu citizen of Jewish descent. ${ }^{2}$

Along with other Swedish laws, the 1782 regulations concerning Jews remained in force, as Finland became a Grand Duchy within the Russian Empire in 1809. Because of the high esteem enjoyed by the traditional laws of Sweden, the Grand Duchy of Finland remained a country out of bounds to Jews. 
However, there is an exception which proves the rule. A part of southeastern Finland, so-called Old Finland, was incorporated into Russia as early as the middle of the I8th century, and Swedish laws did not apply to that area until I8II. This made it possible for some Jewish families to move from Russia proper to Old Finland at the end of the I79os; several families (Jacobsson, Kaspi, Veikkanen etc.) in Finland are descendents of these Jewish pioneers. An earlier case is Jan da Costa (Lakosta), a court jester and "the Jew of Peter I", who was granted by the Czar the honorary title "King of Samoyeds" and an estate which consisted of the islands Lavansaari, Suursaari (Gogland), Tytärsaari and Seiskari in the Finnish Gulf. Jan da Costa built a manor house in Lavansaari, and he is told to have sailed to other islands to collect taxes. ${ }^{3}$

The Grand Duchy of Finland was a country out of bounds to Jews. However, when the Jews were granted civil rights in the independent Republic of Finland in 1918, I,400 Jews were living in the country. How do we explain this miracle?

The regulations prohibiting the entry of Jews into the Grand Duchy of Finland did not prevent the Russian Army from entering the country. Ever since 1827 , the Jews of Russia were liable for military service. With very few exceptions, Jews came to Finland as soldiers of the Czarist army. During the reign of Emperor Nicholas I, the duration of military service could well be 25 years - and even later it was six years. The conversion of non-Christian soldiers was one of the aims of the prolonged period of service. As one can imagine, the Jews in Russia did not consider the conscription to be a great honour, and thus the majority of Jewish recruits were sons of the poorest families, orphans and other of the underprivileged, many of them handed over to the army by the notorious chapers, i.e. kidnappers. After the long years of service, the soldiers, often having lost all contact with their birthplaces, were inclined to stay where they were.

This rype of settlement caused a problem for Finnish autonomy. As a reaction, a Russian military ukase was issued in 1858 concerning soldiers discharged from the Russian army. According to this decree, a soldier in possession of a letter of retirement, a passport or a travel document had the right to settle and support himself in Finland. The same right applied to his family and children and also to his widow. As I have mentioned before, the decree was originally a Russian ukase, not a regulation promulgated by an initiative of the autonomous authorities in Finland. The ukase did not make any distinction between Christian and non-Christian soldiers, and the right of settlement of Jews was only implied from the general wording dealing with all ex-soldiers. Similarly, Moslems veterans were allowed to stay in Finland after that. Later, by a Finnish decree of 1869 and a letter from the Finnish 
Senate in 1876 , ex-soldiers and their families were entitled to earn a living by selling home-made handicrafts, bread, berries, cigarettes, second-hand clothes and other inexpensive textile products. This type of trading was in which the Jewish narinkka markets in Helsinki began. ${ }^{4}$

At the beginning of the I870s, organizational reforms in the Russian army brought about a rapid increase in the number of Jews in Finland to about five hundred - such a high figure! 5 As a consequence, in 1872 a debate on their legal status was initiated in the Finnish Diet.

The four estates of the Diet, as well as the political parties of the subsequent Parliament, Senate, were unable to provide a solution to the problem. General conservatism, national protectionism and the fear of a mass exodus of the Eastern European Jewish proletariat were the main arguments of the opponents. The constitutional conflict between the Finnish and Russian authorities which began in 1899 further complicated the handling of the question. ${ }^{6}$

It was only in 1918, in connection with Finnish independence, that full citizen's rights were granted to the Jews in Finland. In Europe, only Rumania acted more slowly than Finland in giving civil rights to the Jewish population. In Russia Jews were naturalized after the Revolution in 1917, and in Sweden this was achieved as early as 1870. - In this context it is worth noting that the great majority of Jews living in Sweden and other Scandinavian countries have a German background; immigration from Poland has also taken place.

Because of the restrictions, extremely few Jews could move to Finland on their own initiative. On the basis of the Finnish police archives it is evident that, excluding the intelligentsia, which was very small in number (a rabbi, a teacher and a circumciser), the background of all Jews was in one way or another in the Russian Army. They had not just come to Finland, it was the Army which had sent them - by chance - to Finland and finally they had settled in the country. The decision was not their own; it was a part of the inexplicable wisdom of the Army which chose who would be Jews of Finland in the future. No parallel case of this sort of genesis of a Jewish community is known to me.

The Russian Army thus sent Jews to Finland. However, a very important exception from this rule must not be forgotten. While the Army sent boys to Finland, it did not take care of providing wives for them. Actually, we have no precise information as to the measures to which the poor lonely soldiers resorted. Family legends tell of veterans who established a joint "isqa venture, i.e. they collected money and wrote a letter to a rabbi in a shtetl in Lithuania asking him to dispatch so-and-so many marriageable Jewish women to Helsinki. Since trains were few in Russia, a consignment was transported by a cart. The ex-soldiers had plenty of time to spend waiting in the market place 
in Helsinki, and when the cart at last arrived, the strongest khaveyrim were ready to take the most beautiful meydelakh down from the wagon; the slimmer lads had to be happy with the rest. The story has given rise to a saying current among Jewish ladies in Finland: "I have not been taken down from a cart" - i.e. "I come from a better mishpokhe."7

Be that as it may be, it is evident that other nationalities in Russia were attracted to Finland by its reputation in Russia as a country of order, a strong economy and greater intellectual freedom. ${ }^{8}$ Obviously it was this reputation which assisted the Jewish soldiers in obtaining wives from Russia with such success that in 1898 the majority of Jews living in Helsinki were born in Finland; this genesis was due to the great number of children in their families.

From which parts of Russia were the Jewish soldiers sent to Helsinki? The Helsinki police archives offer a clear answer to this question. All Jews resident in Helsinki in 1898 had come from Russia which at that time included the greater part of Poland. ${ }^{9}$ According to the archives the most important "home towns" or the localities and districts where the heads of the families had been registered before their arrival in Finland, were (I) Schlüsselburg (now Petrokrepost) east of St. Petersburg, above the River Neva, (2) the governments of Novgorod and Tver, and (3) Lithuania and the north-eastern parts of Poland. A surprising element in this information is that Schlüsselburg, Novgorod and Tver were all outside the Pale of Settlement where Jews were allowed to reside. Equally surprising is the almost total absence of Estonia and Latvia in the domicile registers. ${ }^{10}$

During the first decades of independent Finland, in the 1920s and 1930s, the Jewish population in Finland numbered nearly 2,000, more than at any other time. At the outset, Jews spoke either Yiddish or Russian. Linguistic assimilation led first in the direction of Swedish and then also in the direction of Finnish. Yiddish was discarded surprisingly quickly; a student of mine could find only three speakers of Yiddish for tape-recording for his M.A. thesis in Helsinki in 1995. In giving up the Jewish language, Yiddish, Finnish Jewry was left without a significant uniting factor, a factor which, for example, the Finnish Tatars have preserved. ${ }^{11}$ Religion and consciousness of being Jewish remained, thereafter, the only uniting factors.

In the 1920s and I930s, genuine anti-Semitism also found expression in Finland in certain ultra-right-wing circles, but it never gained wider sympathies. The fact seems to remain that in the young Republic all minorities suffered from prejudice and xenophobia to some extent but evenly distri- 
buted. In this period, the Jews did, however, carry one burden which may have made their position more difficult than that of other minorities: a significant number of the Soviet leaders and well-known Bolsheviks were Jews, and this fact easily led people to the following conclusion: because he is a Jew he must be a Bolshevik, and as such an enemy of Finland.

\section{WORLD WAR II ${ }^{12}$}

In the years 1939-I944 two different wars against the Soviet Union were imposed upon Finland. During the Winter War of 1939-1940 Germany remained strictly neutral on the basis of the Molotov-Ribbentrop Pact; Great Britain and France planned intervention in favour of Finland.

When the second, so-called Continuation War broke out in the summer of 194I, Finland was a co-belligerent of Germany, and Great Britain declared war on Finland in December 1941. De jure, however, Finland was never an ally of Germany, and at the end of the War, in the winter 1944-45, the Finnish armed forces expelled the German troops from Lapland, which was devastated by the Germans during their retreat to Norway.

Military service was compulsory for each male citizen of Finland. In 1939 the Jewish population of Finland numbered 1,700 . Of these, 260 men were called up and approximately 200 were sent to serve at the front during the Winter War. Fifteen men lost their lives. In comparison with other communiries in the country, the Jewish losses ( $8 \%$ ) were conspicuously heavy. However, it is obvious that the Winter War did not involve ideological problems neither for the Jews nor for other citizens of Finland. In this respect a statement made by a Jewish veteran seems to be characteristic: "The Winter War gave us a deeper consciousness of being Finnish and of belonging to Finland more than any earlier period in our history."

As I mentioned earlier, the Continuation War broke out in the summer of 1941. Now Finland was a co-belligerent of Germany, and there were Wehrmacht and Waffen-SS troops in the country. However, no Einsatzgruppe was sent to Finland.

The comradeship-in-arms with Germany during the Continuation War did not alter the status of Jews in Finland or in its army. Jewish citizens served in the Finnish army, in women's voluntary defence services and in other duties alongside other Finns. The same was true with regard to all the ethnic minorities, Tatars, Russians, Gipsies, Lapps, without differentiation.

In a quite unique photo, in a snowy forest there is a millboard tent with an iron heating stove, the chimney on the left-hand side - and a number of 
soldiers are posing outside the tent. The tent is a field synagogue, "Scholka's shul", set up for the Jewish soldiers at the front beside the River Svir in Eastern Karelia. A field synagogue with a Torah Scroll was, no doubt, a very exceptional event in an Army fighting on the German side during the War.

Several Jewish soldiers were cited for bravery in action; a number of them served as company commanders and one as a captain and battalion commander; Jewish army doctors were promoted to the same officer ranks as their colleagues, inclusive of ranks of major.

During the two wars, 23 Finnish Jews were killed in action. As a tribute to their memory, their names are published annually in the Jewish Calendar of the Bicur Cholim Society in Helsinki.

It has been supposed that the Germans demanded the liquidation of the Jewish communities in Finland too. However, there is no evidence in favour of these claims. On the other hand, the small Jewish population of Finland was not rescued because of a "lapse of memory" among the Nazis as has sometimes been maintained. An evident confutation of this hypothesis is the case of a handful of Jewish citizens from Finland who were living in the Germanoccupied countries: their successful return to Finland resulted in intense diplomatic activity between Berlin and Helsinki in the spring and summer of I943.

It was the public conviction that "we have no Jewish Question", and the Finnish prime minister J.W. Rangell expressed such an opinion to Heinrich Himmler in July 1942. Consistent messages of this kind may have warned the Germans not to endanger relations with their useful brother-in-arms over an insignificant matter of little advantage to them - after final victory there would be nowhere for the Jews to escape to.

The position of Finnish Jewish soldiers was very similar to the political reality: none of the Jewish citizens of Finland refused to enter military service on the grounds of pacifism or of being Jewish. On the other hand, no instance is known of German soldiers refusing to co-operate with Finnish Jewish officers. As a rule, the attitude of Germans to Jewish soldiers in the Finnish army has been described as an "astonished" but "correct" one. The usual answer to incredulous questions put by Germans was that "there is no difference between Jews and other soldiers in the Finnish army." A number of Jewish officers were awarded German Iron Crosses, but they refused them.

Jewish soldiers were not unaware of the general anti-Semitism of Hitler's Germany, and reports of atrocities and mass murders circulated among them and their families. However, the brutality of the Holocaust did not become evident until the end of the Continuation War in the autumn of $x 944$. The awareness of being Finnish soldiers gave the Jews an assurance of safety even 
in the vicinity of German troops. At the same time, quite a number of Jewish soldiers seem to have felt the need to display that they were at least as brave soldiers as their comrades.

The complexity of comradeship with the Germans became a serious problem only after the wars, when the extent of the Holocaust was revealed. First of all, the Norwegian Jews who had suffered most during the Nazi occupation questioned the policy of the Jews in Finland. I consider that two reactions to these questions illustrate the views of the Jews in Finland quite well. A former Jewish member of the women's voluntary defence services (lotta) told me: "We were very surprised because of these questions. We were proud that we were also accepted to join the other Finns." Another reaction was: an association called the Jewish War Veterans in Finland was founded in Helsinki in 1981. During the first year of the association's activity, 84 members, more than Io per cent of the members present in the Community, joined the association. It is self-evident that this is a most valid piece of evidence in favour of the exceptional, independent nature of the war which Finland waged on the side of Germany.

This is a short account of the Jewish citizens of Finland during the War. Another story is that of the Jewish refugees.

The persecution of Jews, launched by the National Socialists in Germany and in other countries under their influence, also brought refugees to Finland, where, however, they were received in a rather reluctant manner. In all, about 500 refugees arrived, and of these, 350 had by the summer of 194I continued their journey to a third country, mostly to Sweden or the United States.

In contrast to the Jewish citizens of Finland, the position of the refugees turned out to be very difficult during the Continuation War. Some of the refugees were German nationals, and others had escaped to Finland from countries allied with or conquered by Germany. When the Continuation War broke out in I94I there were about I5O Jewish refugees in Finland. They were taken to two villages in the countryside, but 43 men were sent to work-camps first in southern Lapland (Salla) and then to the Isle of Suursaari (Gogland) in the Finnish Gulf.

In the autumn of 1942 , Norwegian Jewry was annihilated; more than half of them (altogether 757 people) lost their lives. Most of the survivors were among those who succeeded in escaping to Sweden. As I have mentioned before, it has been supposed that the Germans demanded the liquidation of the Jewish communities in Finland. However, there is no documentary evidence in favour of these claims, either concerning the Jewish citizens or the refugees. ${ }^{13}$

Nevertheless, the State Police in Finland had agreed with the leaders of the 
Gestapo that Finland was allowed to deport the undesirable refugees to the areas occupied by the Germans. In October 1942 nine Jewish men were sent by the Finnish State Police from the Suursaari camp to Helsinki and ten Jews were arrested elsewhere in Finland. However, one of the men escorted from the Suursaari camp succeeded in sending a postcard to Mr. Abraham Stiller, a member of the Jewish community and brother of the famous stage-manager Mauritz Stiller. Stiller as well as his friends, both Jews and other Finns, made contact with various governmental and administrative organs including President Risto Ryti and Marshal of Finland Mannerheim. As a result the governmental and public discussions the extradition was prevented.

However, on the 6th of October 1942, the State Police had already had five Jewish men and three (or four?) members of their families deported to the Gestapo in occupied Estonia. Officially, the men were claimed to be guilty of espionage and other criminal activities; two of them had minor offences in police records. Nineteen other persons, most of them citizens of the Soviet Union, were deported on board the same boat. The Gestapo transported the Jews first to Berlin and then to Auschwitz concentration camp. Only one of these people (Georg Kollman, a former citizen of Austria) survived; after the war he immigrated to Israel.

There is no need to try and wash away the shame, but it should also not be forgotten that in October 1942, Germany was at the height of its power. After Stalingrad, it was considerably easier to say no. When after the war the victor, the Soviet Union, issued the demand that the Finnish Ingrians and other refugees be handed over to the Soviet Union, it was influential enough to get what it wanted.

Of the Jewish refugees, Finnish citizenship was granted to IIo persons in I943-44; some of them left the country before that or later on.

Among the Russian prisoners-of-war there were approx. 500 Jews in Finland. In autumn 1942 they were collected to two special camps where they had a privilege to receive food supply and other help granted by the Jewish communities in Finland and Stockholm.

On the Finnish Independence Day, the 6th of December, in 1944, President Mannerheim, Marshal of Finland, visited the synagogue in Helsinki where the memory of the Jewish soldiers killed in action was honoured. When Mannerheim died in I95I, the Jewish community raised a large sum of money which was donated to the Mannerheim Fund of Child Welfare as an expression of gratitude for the defence of the equal rights of Jews in Finland. 


\section{Notes}

I. Jews expelled from Portugal in the i6th century settled in the Dutch cities and in Hamburg. Their offspring and communities were for centuries called Portuguese. The word is here used in this sense.

2. Another famous convert was Meyer Levin, who in 1799 was admitted to the Medical Faculty of the University of Turku. Later on, Levin worked at the University teaching German, and in I8IS he was given a permit to set up a printing house.

3. Tapani Harviainen, "Lavansaaren herra Johan da Costa, Suomen ensimmäinen juutalainen" (Jedidut, Suomi-Israel Yhdistysten Liitto ry), 4/1998, pp. 10-I5.

4. From Russian na rynke 'at the market-place'.

5. In the earliest list of Jews in Helsinki of which I am aware, drawn up in 1868,21 families with 83 family members were enumerated (National Archives, KKK $36 / 1686$ ).

6. In a letter of the Finnish Senate written in 1889 , certain Jews whose names were particularly mentioned, together with their families, were given the right to remain in Finland until further notice, and to reside in localities assigned to them. From these towns Jews were allowed to move only to Helsinki or Vyborg within Finland. The residence permit applied to children only as long as they lived with their parents. As soon as they married or entered military service, they lost their residential right. New Jews were no longer admitted to Finland.

At first "residence tickets" were very strictly scrutinized, and because of the problem of marriage, many Jews moved away from Finland and others were expelled. In 1890 , there were about one thousand Jews in Finland, but in five years their number decreased by one quarter. At the turn of the century the practice of examining and renewing residence permits was no longer observed, but the regulation remained officially in force until rgr8.

7. Helsingin Sanomat (A. Hurwitz), no. 316, 21.II.1929, s. 4 .

8. This conclusion is confirmed e.g. by the article Eyn vokh in Finland by Shemarya Gorelik, who participated in the 1906 Russian Zionist Congress in Helsinki. The article was published in Dos yudishe folk in Vilna the same year, and it was almost comic in its praise of the Finns and conditions in Finland.

9. Most of the soldiers had served in the regiments of the 23 rd division then stationed in Finland (the regiments of Dvinsk, Petshora, Onega and Belomorsk), but quite a few also in different auxiliary units (military hospitals, local detachments, feeding depots etc.). Among them were also many bandmasters, members of military bands and drummers.

IO. In the r880 and 1890 s nearly all Helsinki Jews made their living by selling new and second-hand clothes and fruit at the narinkka market: the name of Simo (i.e. Simeon) Square still refers to the Jewish market. More than three quarters of the Jewish population lived in the same district of Kamppi, where both the narinkka (from 1876 ) and later also the synagogue (from 1906) were located. As late as 1860 s most Jews still lived in the districts of Siltasaari and Kruununhaka, where the market was located at the time.

Ix. These Tatars also derive their origin from Russia, from the region of Nizhniy Novgorod, east of Moscow. Although Tatars also served in the Russian army in Finland, they did not settle in the country as ex-soldiers; their forefathers came to Finland as pedlars of clothes and furs. In 1925 they established a Moslem congregation in Helsinki. As in the case of the Jews, the members of the Tatar community have been able to adapt themselves to Finnish society without radical difficulties; both of these minorities are of the same size, viz. one thousand persons. Besides being a religious congregation, the Tatar Moslem community has stressed national aspects, retention of the Turkic Tatar language, traditional habits and close family ties. In spite of competition in a number of lines of business, rela- 
tions between the Tatar and Jewish minorities have been good; a sign of the rapport between them is a friendly football match arranged by them each spring.

I2. For the wartime history, see Hannu Rautkallio, Suomen juutalaisten aseveljeys (The comradeship-in-arms of the Jews of Finland). Tammi, Helsinki-Jyväskylä 1989. 250 p., ill., English summary), and Robert D. Rachlin, "How were they Saved? Finland, the Second World War, and the Jews" (The Bulletin of the Center for Holocaust Studies at the University of Vermont, Vol. 3, Number 2, Spring 1999, pp. 7-14).

13. The fate of the Jewish refugees in Finland has been the subject of lively discussion, see Elina Suominen, Kuolemanlaiva S/S Hohenhörn ('Ship of Death S/S Hohenhörn', Porvoo 1979); Taimi Torvinen, Pakolaiset Suomessa Hitlerin valtakaudella ('Refugees in Finland during the rule of Hitler', Keuruu 1984); Hannu Rautkallio, Finland and the Holocaust, the Rescue of Finland's Jews ( 1987 ). 